Tropical Journal of Pharmaceutical Research October 2021; 20 (10): 2219-2226

ISSN: $1596-5996$ (print); 1596-9827 (electronic) (C) Pharmacotherapy Group, Faculty of Pharmacy, University of Benin, Benin City, 300001 Nigeria.

\title{
Effects of different immunosuppressive drugs on the periodontal status and changes in periodontal pathogenic bacterial flora in rheumatoid arthritis patients
}

\author{
Zhihai Wu ${ }^{1}$, Xuguang Yang ${ }^{2}$, Ning $\mathrm{Li}^{3 *}$ \\ ${ }^{1}$ Department of Stomatology, Lanzhou Anning District People's Hospital,Lanzhou, Gansu 730070, ${ }^{2}$ Department of Anatomy and \\ Histology, School of Basic Medical Sciences, Lanzhou University, Lanzhou, Gansu 730000, ${ }^{3}$ Department of Stomatology, \\ Gansu Gem Flower Hospital, Lanzhou, Gansu 730060, China
}

*For correspondence: Email: 1004089564@qq.com; Tel/Fax:0086-13567884556

\begin{abstract}
Purpose: To investigate the prevalence of periodontal disease(s) and the associated bacteria among rheumatoid arthritis (RA) patients treated with different immunosuppressive drugs.

Methods: Patients aged 18 - 65 years who had a 6-month history of RA, and were diagnosed as per the American College of Rheumatology and European League against Rheumatism, were included in the study. Supragingival plaque was removed by dentists. Using sterile paper strips, sub-gingival biofilm samples were collected from 5 of the deepest periodontal pockets. The samples were sent to pathologists for assessment. Polymerase chain reaction was carried out on them. Detection thresholds were $>10^{2}$ for Aggregatibacter actinomycetemcomitans, while the detection threshold for Porphyromonas gingivalis, Tannerella forsythia, Treponema denticola, Prevotella intermedia, Parvimonas micra, Fusobacterium nucleatum, Campylobacter rectus, Eubacterium nodatum, Eikenellacorrodens, and Capnocytophaga species was $10^{3}$.

Results: There was a higher number of patients with bleeding-on-probing amongst cohorts who received a combination of methotrexate and tumor necrosis factor- $\alpha$ antagonist than in those given leflunomide only (52 vs. 29, $p=0.041, q=3.064$ ), or methotrexate + rituximab (52 vs. 30, $p=0.041, q=$ 3.131, Fig. 1). Papilla bleeding index was lowest in patients who were treated with leflunomide. Almost all patients had dental infection with Fusobacterium nucleatum.

Conclusion: These results indicate that treatment of $R A$ with methotrexate results in periodontal inflammation.
\end{abstract}

Keywords: Bleeding on probing, Dental examination, Methotrexate, Periodontal inflammation, Rheumatoid arthritis

This is an Open Access article that uses a funding model which does not charge readers or their institutions for access and distributed under the terms of the Creative Commons Attribution License (http://creativecommons.org/licenses/by/4.0) and the Budapest Open Access Initiative (http://www.budapestopenaccessinitiative.org/read), which permit unrestricted use, distribution, and reproduction in any medium, provided the original work is properly credited.

Tropical Journal of Pharmaceutical Research is indexed by Science Citation Index (SciSearch), Scopus, International Pharmaceutical Abstract, Chemical Abstracts, Embase, Index Copernicus, EBSCO, African Index Medicus, JournalSeek, Journal Citation Reports/Science Edition, Directory of Open Access Journals (DOAJ), African Journal Online, Bioline International, Open-J-Gate and Pharmacy Abstracts

\section{INTRODUCTION}

Periodontitis and RA are inter-related [1-4]. Periodontitis and RA exhibit multifactorial characteristics, with episodes of progression and stagnation [5]. The pathogenic bacterium involved in periodontitis is Porphyromonas gingivalis [6]. However, cross-sectional studies $[7,8]$ have not succeeded in identifying the key role of Porphyromonas gingivalis in the 
relationship between periodontitis and RA. A cross-sectional study has reported potential imbalance in immunity among patients with periodontitis and RA [9]. There is no clear proof for the pathogenesis of periodontitis under influence of rheumatoid arthritis [5]. Moreover, cross-sectional studies have revealed that the use of multifarious and heterogenous medications may be a risk factor for periodontitis in RA patients $[7,8]$.

Various immunosuppressive and antiinflammatory drugs are affected by RA and periodontal inflammation [5]. A recent cohort study demonstrated that RA treatment influences periodontal infection, and that the RA patients may present with clinical and pathological symptoms of periodontal disease(s) [10]. A cohort study [11] and a comparative investigation [12] reported that pharmacological drugs, especially tumor necrosis factor- $\alpha$ antagonists of RA are associated with periodontal inflammation and periodontal diseases.

The objectives of the present cross-sectional study were to investigate the prevalence of periodontal disease(s) in RA patients treated with different immunosuppressive drugs, and to identify the bacteria responsible for same. In addition, the study was aimed at investigating the association between different immunosuppressive drugs and condition(s) of periodontal diseases. It was hypothesized that differences in RA medication might affect the periodontal conditions of RA patients.

\section{METHODS}

\section{Compliance with ethical standards}

The study design protocol (no. GMNUC L171520) was approved by the institutional review board, and the study carried out in line with the laws of China [11] and 2008 Declarations of Helsinki [12]. An informed consent form was signed by each of the participants or their legally-authorized representative, with respect to diagnosis, pathology, and publication of personal information in an article.

\section{Study population}

The study population consisted of RA patients in the age range of $18-65$ years, who were diagnosed as per the American College of Rheumatology and European League Against Rheumatism [13]. Patients who had a 6-month history of RA were included in the study.
However, RA patients with severe systemic diseases such as diabetes mellitus, chronic heart diseases, endocarditis, delicately-controlled hypertension, renal disease, infectious diseases (HIVIAIDS, hepatitis and tuberculosis); neuropathy, and patients taking other immunosuppressive medications aside from RA therapy (e.g., due to organ transplantation) were excluded. Moreover, patients who were pregnant, and RA patients with limited mobility consistent with function class IV ACR, were excluded from the study.

\section{Sample size calculation}

The level of confidence in this study was taken as $95 \%$. It was assumed that $30 \%$ of the population were exposed to a risk factor, and equal numbers of RA cases and controls in matched study design, with hypothesized odds ratio of 2.0 , level of significance $=5 \%$, and power $=80 \%$. A two-sided test was assumed, and the level of significance was typically assumed as $5 \%$. Type I error is inversely proportional to sample size. Power was taken as $80 \%$, and Type II error is directly proportional to sample size. The formula used for calculating sample size was:

$n=[(Z \alpha / 2+Z \beta) 2 \times\{(p 1(1-p 1)+(p 2(1-p 2))\}] /(p 1$ - p2)2

where $n=$ sample size required in each group, p1 = proportion of subjects treated in group $\mathrm{I}=$ $0.50 ; p 2=$ proportion of subjects treated in group $I I=0.34 ;(p 1-p 2)=$ clinically significant difference $=0.16$. $Z \alpha / 2$ : This depended on level of significance. At $5 \%$, the value was 1. 96Zß: This depended on power. For power of $80 \%, 96 Z \beta$ was 0.84 . Based on the above formula, the total sample size required was 100 . However, this study was designed to follow strict inclusion criteria and follow-up plan. If $n$ is the sample size required as per the formula, and if $d$ is the dropout rate, then adjusted sample size $N 1$ was calculated using the formula:

$N 1=n /(1-d)$, and at maximum dropout of $20 \%$ per group. Therefore, 20 subjects were added. Thus, based on the calculations, the total sample size was taken as 111 .

\section{Demographical and clinical conditions}

Data regarding clinic-pathological conditions, current treatment for RA, Disease Activity Score (DAS28-ESR) [14], antibodies against cyclic citrullinated peptide, and rheumatic factor were collected and analyzed. 


\section{Clinical dental examination}

The periodontium was assessed to identify periodontitis using Community Periodontal Index of Treatment Need (CPITN). The papilla bleeding index (using a periodontal probe) was determined as an index of gingival inflammation. Periodontal condition was assessed using periodontal probing depth, bleeding on probing, and classification of clinical attachment loss [none/mild periodontitis, moderate periodontitis (interproximal sites of $2 \mathrm{~mm}$ or more, with clinical attachment loss of $4 \mathrm{~mm}$ or more, not on the same tooth, or interproximal sites of $2 \mathrm{~mm}$ or more, with probing depth of $5 \mathrm{~mm}$ or more); severe periodontitis (interproximal sites of $2 \mathrm{~mm}$ or more, with clinical attachment loss of $6 \mathrm{~mm}$ or more on different teeth, or interproximal site of 1 $\mathrm{mm}$ or more, with the probing depth of $5 \mathrm{~mm}$ or more] [7, 15]. The clinical examinations were carried out by dentists with minimum experience of 3 years, and they were naïve to the immunosuppressive therapies used.

\section{Microbiological analysis}

The supra-gingival plaque was removed by dentists, and using sterile paper strips, subgingival biofilm samples were collected from five of the deepest periodontal pockets. The samples were sent to pathologists for analysis. A commercial polymerase chain reaction (MicroIDentplus-Test, HainLifescience, Nehren, Germany) was performed by pathologists with minimum experience of 3 years. They were unaware of the immunosuppressive therapies used. The detection thresholds were $>10^{2}$ for Aggregatibacter actinomycetemcomitans, while the detection threshold for Porphyromonas gingivalis, Tannerella forsythia, Treponema denticola, Prevotella intermedia, Parvimonas micra, Fusobacterium nucleatum, Campylobacter rectus, Eubacterium nodatum, Eikenella corrodens, and Capnocytophaga species, was $10^{3}[5]$.

\section{Statistical analysis}

The SPSS Statistics version 25.0 software (IBM Corporation, Armonk, NY, USA) was used for statistical analyses. Metric variables were examined as per their normal distribution using the Kolmogorov-Smirnov test. A univariate analysis of variance (ANOVA) was used for comparisons of normally-distributed data. The Kruskal- Wallis test or the Mann-Whitney U-test was used for comparisons of non-normally distributed data. $\mathrm{C}$ ategorical variables such as the various immunosuppressive drugs, were compared with Chi-square test or the Fischer exact test. Bonferroni- test [considering critical value $(q)>3.047$ as significant] was used for post hoc analysis. Differences were considered significant at $p<0.05$.

\section{RESULTS}

\section{Study population}

From 15 January 2017 to 1 May 2019, a total of 991 patients were diagnosed with RA by rheumatologists at our Institute, and they were treated with different immunosuppressive drugs. Non-steroidal anti-inflammatory drugs such as salicylic acid and non-acidic COX-2 selective glucocorticoids such as methylprednisolone, prednisolone, leflunomide, tumor necrosis factor$\alpha$ antagonist, interleukin-6 antagonist, methotrexate, rituximab, and/or diseasemodifying antirheumatic drugs such as ciclosporin and cyclophosphamide, were used. It was observed that $85 \mathrm{RA}$ patients reported with severe systematic disease(s); 12 RA patients were on additional immunosuppressive treatment(s); I RA patient was pregnant, while 4 patients had class IV ACR, and 27 patients were treated with antibiotic(s) in the previous 3 months. Therefore, these patients $(n=129)$ were excluded from the analysis. Thus, a total of 862 patients were included in the study. The total duration of the study was 34 months. However, selection and collection of subgingival samples were done within 15 months.

\section{Demographical and clinical conditions}

Based on the different immunosuppressive drugs used, the study population was divided into subgroups. There were no significant differences in all parameters in demographical and clinical conditions amongst the enrolled patients, notwithstanding that they were put on different immunosuppressive drugs $(p>0.05 \mathrm{l}$; Table 1).

\section{Clinical dental examination results}

Decayed, missing and filled teeth index; teeth with reasonable cavitation on the surface, missing teeth, crowded or filled teeth, periodontal probing depth, and the clinical attachment loss were comparable amongst all cohorts $(p>0.05$, Table 2). Higher numbers of patients reported with bleeding on probing in MT cohort than in LM cohort (52 vs. 29, $p=0.041, q=3.064$ ), and MR cohort (52 vs. 30, $p=0.041, q=3.131$; Figure 1). Papilla bleeding index was lowest in the LM cohort (Figure 2). The severity of the periodontal disease in each cohort is presented in Figure 3. Porphyromonas gingivalis was reported in higher 
numbers of patients of LM cohort than in patients of IL cohort (72 vs. 47, $p<0.0001, q=3.698$ ); MR cohort (72 vs. 38, $p<0.0001, q=4.938$ ), and DM cohort (72 vs. 51, $p<0.0001, q=3.529$. Moreover, it was seen in higher numbers of patients of MT cohort than in those of IL cohort (74 vs. 47, $p<0.0001, q=3.405)$; MR cohort (74 vs. $38, p<0.0001, q=4.656)$, and DM cohort (74 vs. 51, $p<0.0001, q=3.229$ ). Tannerella forsythia was reported in fewer numbers of patients of MR cohort than in patients of NG cohort (73 vs. 119, $p<0.0001, q=5.667$ ); $\mathrm{MX}$ cohort (73 vs. 95, $p<0.0001, q=4.381)$; LM cohort (73 vs. 105, $p<0.0001, q=5.779$ ); MT cohort (73 vs. 96, $p<0.0001, q=3.779$ ); IL cohort (73 vs. 93, $p<0.0001, q=3.086$ ), and DM cohort (73 vs. 98, $p<0.0001, q=3.194$ ).

There were higher number of patients with Treponema denticola infection in patients of NG cohort than those of IL cohort (93 vs. 61, $p<$ $0.0001, q=3.229$ ) and MR cohort (93 vs. 38, $p<$ 0.0001, $q=5.894)$. Treponema denticola was reported in higher numbers of patients of $M X$ cohort than in patients of IL cohort (83 vs. $61, p<$ $0.0001, q=3.633$ ); MR cohort (83 vs. $38, p<$ $0.0001, q=6.192$ ), and DM cohort (83 vs. 33, $p$ $<0.0001, q=3.172$ ). Higher number of patients had Treponema denticola in LM cohort than in MT cohort (81 vs. 71, $p<0.0001, q=5.475$ ). Almost all patients had dental infection with Fusobacterium nucleatum. The detailed results of microbiological analyses are reported in Table 3.

\section{DISCUSSION}

In this study, RA patients who received methotrexate plus tumor necrosis factor- $\alpha$ antagonist had the highest incidents of bleeding on probing. Moreover, these patients had higher papilla bleeding index than those who were treated with leflunomide. The observed periodontitis was caused by tooth infection due to Porphyromonas gingivalis, Treponema denticola, Fusobacterium nucleatum, and Capnocytophaga. The results of the current study are in agreement with those obtained in earlier studies $[10,16,17]$.

Motor restrictions of patients are responsible for their poor oral health conditions [18]. Disease burden, poor quality of life, and impairment of daily life are also responsible for the poor periodontal situations observed [19]. Methotrexate increases the apoptosis of T-cells and reduces cell proliferation [5]. Porphyromonas gingivalis and Aggregatibacter actinomycetemcomitans may contribute to RA through citrullinated peptides [20]. Patients with RA may have periodontal diseases and pathogenic periodontal bacteria in their dental cavities.

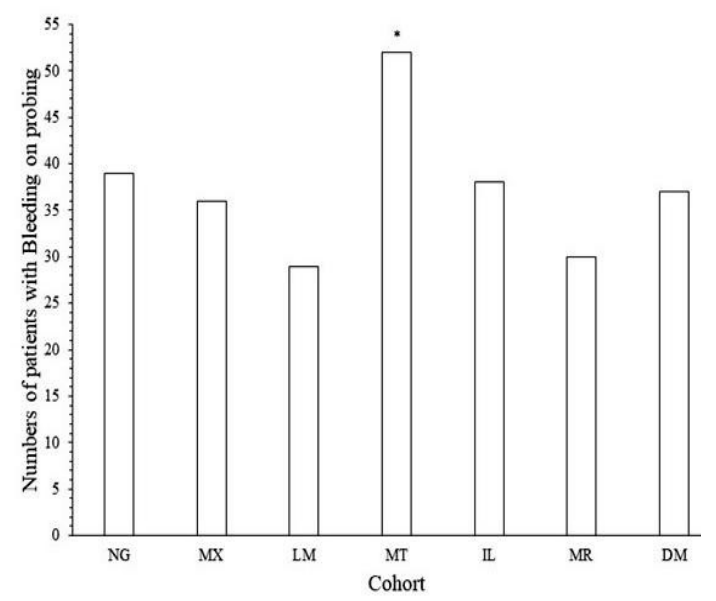

Figure 1: Bleeding on probing. *Significantly higher than in LM and MR cohorts

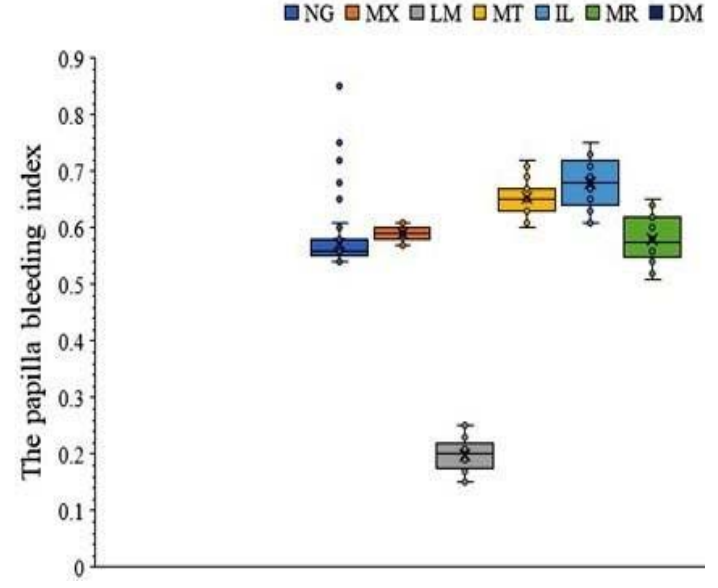

Figure 2: Papilla bleeding index

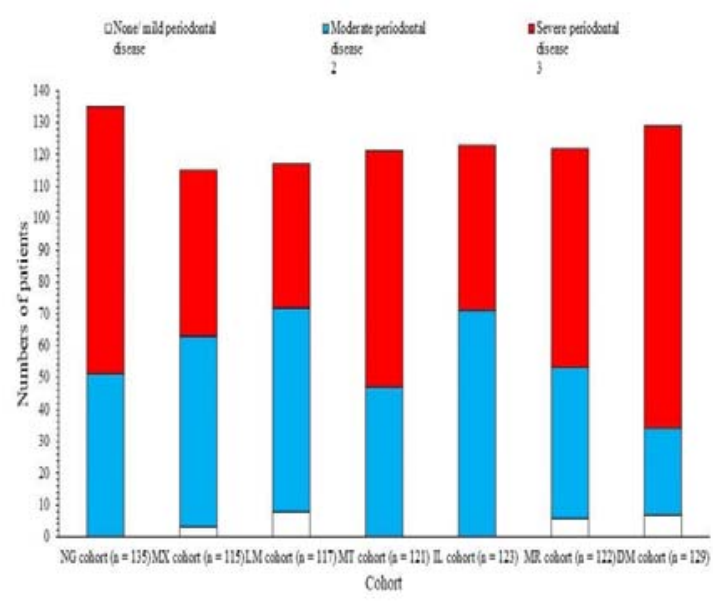

Figure 3: Severity of periodontal disease 
Table 1: Demographical and clinical conditions of the enrolled patients

\begin{tabular}{|c|c|c|c|c|c|c|c|c|}
\hline $\begin{array}{l}\text { Cohort } \\
\text { variable }\end{array}$ & NG & $\begin{array}{l}\text { MX } \\
\text { Methotrexate }\end{array}$ & $\begin{array}{l}\text { LM } \\
\text { Leflunomide }\end{array}$ & $\begin{array}{l}\text { MT } \\
\text { Methotrexate + tumor } \\
\text { necrosis factor- } \alpha \\
\text { antagonist }\end{array}$ & $\begin{array}{l}\text { IL } \\
\text { Itraleukin-6 } \\
\text { antagonist }\end{array}$ & $\begin{array}{l}\text { MR } \\
\text { Methotrexate + } \\
\text { rituximab }\end{array}$ & $\begin{array}{l}\text { DM } \\
\text { Disease-modifying } \\
\text { antirheumatic drugs } \\
\text { in combination }\end{array}$ & Statistics \\
\hline Patients included & 135 & 115 & 117 & 121 & 123 & 122 & 129 & $P$ \\
\hline Minimum Age & 45 & 45 & 45 & 46 & 45 & 46 & 45 & \\
\hline Maximum (years) & 75 & 74 & 75 & 74 & 75 & 75 & 75 & 0.763 \\
\hline Mean \pm SD & $57.47 \pm 9.42$ & $61.12 \pm 11.15$ & $59.44 \pm 40.18$ & $60.24 \pm 11.37$ & $59.27 \pm 10.42$ & $58.45 \pm 10.44$ & $58.88 \pm 9.45$ & \\
\hline Males & $30(22)$ & $29(25)$ & $28(24)$ & $25(21)$ & $31(25)$ & $26(21)$ & $35(27)$ & \\
\hline Females & $105(78)$ & $86(75)$ & $89(76)$ & $96(79)$ & $92(75)$ & $96(79)$ & $94(73)$ & 0.889 \\
\hline $\begin{array}{l}\text { Smokers } \\
\text { Han }\end{array}$ & $27(20)$ & $25(22)$ & $22(19)$ & $23(19)$ & $28(23)$ & $24(20)$ & $31(24)$ & 0.935 \\
\hline $\begin{array}{l}\text { Ethnicity } \\
\text { Chinese }\end{array}$ & 124(92) & 106(92) & 108(92) & 112(93) & 113(92) & 113(93) & $117(91)$ & 0.998 \\
\hline Mongolian & $10(7)$ & $8(7)$ & $8(7)$ & $8(6)$ & $9(7)$ & $8(6)$ & $11(8)$ & \\
\hline Tibetan & $1(1)^{\prime}$ & $1(1)$ & $1(1)$ & $1(1)$ & $1(1)$ & $1(1)$ & $1(1)^{\prime}$ & \\
\hline $\begin{array}{l}\text { Disease Activity } \\
\text { Score Antibodies } \\
\text { against }\end{array}$ & $3.65 \pm 1.72$ & $3.82 \pm 1.65$ & $3.91 \pm 1.58$ & $3.87 \pm 1.35$ & $3.73 \pm 1.27$ & $3.78 \pm 1.59$ & $3.65 \pm 1.62$ & 0.777 \\
\hline $\begin{array}{l}\text { Cyclic citrullinated } \\
\text { peptide positive }\end{array}$ & 13(10) & $12(10)$ & $8(7)$ & $15(12)$ & $17(14)$ & $19(16)$ & 18(14) & 0.377 \\
\hline $\begin{array}{l}\text { Rheumatic factor } \\
\text { positive }\end{array}$ & $18(13)$ & $19(17)$ & $22(19)$ & $23(19)$ & 21(17) & $14(11)$ & 19(15) & 0.626 \\
\hline
\end{tabular}

Categorical data are presented as frequency (percentage) and continuous, while ordinal data are presented as mean \pm standard deviation (SD). Chi-square test was used for comparison of categorical data, while ANOVA was used for comparison of continuous and ordinal data. Differences were considered significant at $p<0.05$ 
Table 2: Clinical dental examination

\begin{tabular}{|c|c|c|c|c|c|c|c|c|}
\hline Cohort & & & & & & & & \\
\hline variable & $\begin{array}{c}\text { NG } \\
\text { Non-steroidal anti- } \\
\text { inflammatory drugs } \\
+ \text { glucocorticoids }\end{array}$ & $\begin{array}{c}M X \\
\text { Methotrexate }\end{array}$ & $\begin{array}{c}L M \\
\text { Leflunomide }\end{array}$ & $\begin{array}{c}I L \\
\text { Methotrexate + } \\
\text { tumor necrosis } \\
\text { factor- } \alpha \text { antagonist }\end{array}$ & $\begin{array}{c}\text { MR } \\
\text { IL- } 6 \\
\text { antagonist }\end{array}$ & $\begin{array}{c}D M \\
\text { Methotrexate + } \\
\text { rituximab }\end{array}$ & $\begin{array}{c}D M \\
\text { Disease-modifying } \\
\text { antirheumatic drugs in } \\
\text { combination }\end{array}$ & $\begin{array}{c}\text { Statistics } \\
P\end{array}$ \\
\hline Patients included & 135 & 115 & 117 & 121 & 123 & 122 & 129 & \\
\hline $\begin{array}{l}\text { Decayed, missing and filled } \\
\text { teeth index }\end{array}$ & $17.11 \pm 3.82$ & $17.45 \pm 4.01$ & $18.01 \pm 3.45$ & $18.36 \pm 4.18$ & $18.37 \pm 5.89$ & $18.44 \pm 3.45$ & $18.22 \pm 3.51$ & 0.063 \\
\hline $\begin{array}{l}\text { Teeth with reasonable } \\
\text { cavitation on surface }\end{array}$ & $0.45 \pm 0.09$ & $0.47 \pm 0.02$ & $0.46 \pm 0.05$ & $0.4 \pm 0.07$ & $0.45 \pm 0.07$ & $0.46 \pm 0.08$ & $0.45 \pm 0.02$ & 0.207 \\
\hline Missing teeth & $3.21 \pm 0.18$ & $3.28 \pm 0.22$ & $3.22 \pm 0.16$ & $3.27 \pm 0.23$ & $3.29 \pm 0.27$ & $3.27 \pm 0.32$ & $3.26 \pm 0.24$ & 0.054 \\
\hline Crowned or filled teeth & $7.11 \pm 2.15$ & $7.24 \pm 2.01$ & $7.15 \pm 2.22$ & $7.18 \pm 1.18$ & $7.16 \pm 1.62$ & $7.22 \pm 1.89$ & $7.19 \pm 1.51$ & 0.998 \\
\hline $\begin{array}{l}\text { Periodontal probing depth } \\
(\mathrm{mm})\end{array}$ & $2.89 \pm 0.81$ & $2.88 \pm 0.85$ & $2.62 \pm 0.91$ & $2.67 \pm 0.89$ & $2.72 \pm 0.81$ & $2.81 \pm 0.79$ & $2.88 \pm 0.91$ & 0.054 \\
\hline $\begin{array}{l}\text { Clinical attachment loss } \\
(\mathrm{mm})\end{array}$ & $2.89 \pm 0.51$ & $2.91 \pm 0.55$ & $2.85 \pm 0.56$ & $2.79 \pm 0.61$ & $2.88 \pm 0.65$ & $2.81 \pm 0.71$ & $2.82 \pm 0.66$ & 0.678 \\
\hline
\end{tabular}

Table 3: Microbiological analyses

\begin{tabular}{|c|c|c|c|c|c|c|c|}
\hline \multicolumn{8}{|c|}{ Cohort (no. of patients who reported positive) } \\
\hline & NG & MX & LM & MT & IL & MR & DM \\
\hline Variable & $\begin{array}{l}\text { Nonsteroidal anti- } \\
\text { inflammatory drugs } \\
+ \text { glucocorticoids }\end{array}$ & Methotrexate & Leflunomide & $\begin{array}{l}\text { Methotrexate }+ \\
\text { tumor necrosis } \\
\text { factor- } \alpha \text { antagonist }\end{array}$ & $\begin{array}{l}\text { Itraleukin-6 } \\
\text { antagonist }\end{array}$ & $\begin{array}{l}\text { Methotrexate + } \\
\text { rituximab }\end{array}$ & $\begin{array}{l}\text { Diseasemodifying } \\
\text { antirheumatic drugs in } \\
\text { combination }\end{array}$ \\
\hline Patients included & 135 & 115 & 117 & 121 & 123 & 122 & 129 \\
\hline $\begin{array}{l}\text { Aggregatibacter } \\
\text { actinomycetemcomitans }\end{array}$ & $9(7)$ & $8(7)$ & $8(7)$ & $2(2)$ & $2(2)$ & $5(4)$ & $2(2)$ \\
\hline Porphyromonas gingivalis & $59(44)$ & $50(43)$ & $72(62)$ & $74(61)$ & $47(38)$ & $38(31)$ & $51(40)$ \\
\hline Tannerella forsythia & $119(88)$ & 95(83) & 105(90) & $96(79)$ & $93(76)$ & $73(60)$ & $98(76)$ \\
\hline Treponema denticola & $93(69)$ & $83(72)$ & $81(69)$ & $71(59)$ & $61(50)$ & $38(31)$ & $69(53)$ \\
\hline Prevotella intermedia & $59(44)$ & $50(43)$ & $24(21)$ & $37(31)$ & $8(6)$ & $38(31)$ & $33(26)$ \\
\hline Parvimonas micra & 125(93) & 95(83) & $81(69)$ & $73(60)$ & 107(87) & $95(78)$ & 103(80) \\
\hline Fusobacterium nucleatum & 130(96) & 113(98) & $115(98)$ & $119(98)$ & 121(98) & 115(94) & 121(94) \\
\hline Campylobacter rectus & $81(60)$ & $71(62)$ & $77(66)$ & 71(59) & 63(51) & $37(30)$ & $87(67)$ \\
\hline Eubacterium nodatum & $58(43)$ & $35(30)$ & $46(39)$ & $47(39)$ & $47(38)$ & $13(11)$ & $39(30)$ \\
\hline Eikenella corrodens & $85(63)$ & $103(90)$ & $56(48)$ & 18(15) & $75(61)$ & $90(74)$ & $90(70)$ \\
\hline Capnocytophaga species & $110(81)$ & $95(83)$ & $93(79)$ & $82(68)$ & $111(90)$ & $83(68)$ & $103(80)$ \\
\hline
\end{tabular}




\section{Limitations of the study}

Oral hygiene parameters were not considered in this study. Patients took the medications for at least six months, but previous medication history, and duration of the medications were not taken into consideration. The differences in severity of periodontal disease might not be have been accurately determined due to high prevalence of periodontitis.

Furthermore, the cross-sectional design did not provide any conclusions about the effect of the medications on clinical and/or bacterial findings. Therefore, there is need for further prospective longitudinal study with an untreated control group to confirm the hypothesis on which this study was based.

\section{CONCLUSION}

Treatment of RA with methotrexate is associated with periodontal inflammation. Conjugant periodontitis treatment is recommended for RA patients. An understanding of the effects of RA treatment may be useful in clinical practice.

\section{DECLARATIONS}

\section{Conflict of Interest}

No conflict of interest associated with this work.

\section{Contribution of Authors}

We declare that this work was done by the authors named in this article, and all liabilities pertaining to claims relating to the content of this article will be borne by the authors. The manuscript was drafted and the data was collected by Zhihai Wu, the statistical analysis was performed by Xuguang Yang. The whole work was designed by Ning Li.

\section{Open Access}

This is an Open Access article that uses a funding model which does not charge readers or their institutions for access and distributed under the terms of the Creative Commons Attribution License (http://creativecommons.org/licenses/by/ 4.0) and the Budapest Open Access Initiative (http://www.budapestopenaccessinitiative.org/rea d), which permit unrestricted use, distribution, and reproduction in any medium, provided the original work is properly credited.

\section{REFERENCES}

1. Araújo VM, Melo IM, Lima V. Relationship between periodontitis and rheumatoid arthritis: Review of the literature. Mediators Inflamm2015. DOI: 10.1155/2015/259074.

2. Rutger Persson G. Rheumatoid arthritis and periodontitis - inflammatory and infectious connections. Review of the literature. J Oral Microbiol2012; 4. DOI: 10.3402/jom.v4i0.11829.

3. Kaur S, White S, Bartold PM. Periodontal disease and rheumatoid arthritis: A systematic review. J Dent Res 2013; 92(5): 399-408.

4. Payne JB, Golub LM, Thiele GM, Mikuls TR. The link between periodontitis and rheumatoid arthritis: $A$ periodontist's perspective. Curr Oral Health Rep2015; 2:20-29.

5. Ainamo J, Barmes D, Beagrie G, Cutress T, Martin J, Sardo-Infirri J. Development of the World Health Organisation (WHO) community periodontal index of treatment needs (CPITN) Int Dent J. 1982;32:281-291

6. Laugisch O, Wong A, Sroka A, Kantyka T, Koziel J, Neuhaus K, Sculean A, Venables PJ, Potempa J, Moller $B$, Eick $S$. Citrullination in the periodontium--a possible link between periodontitis and rheumatoid arthritis. Clin Oral Investig2016; 20(4):675-683.

7. Schmickler J, Rupprecht A, Patschan S, Patschan D, Müller GA, Haak R, Mausberg RF, Schmalz G, Kottmann T, Ziebolz D. Cross-sectional evaluation of periodontal status and microbiologic and rheumatoid parameters in a large cohort of patients with rheumatoid arthritis. J Periodontol2017; 88(4):368-379.

8. Kirchner A, Jager J, Krohn-Grimberghe B, Patschan S, Kottmann T, Schmalz G, Mausberg RF, Haak R, Ziebolz D. Active-matrix metalloproteinase-8 and periodontal bacteria depending on periodontal status in patients with rheumatoid arthritis. J Periodontal Res2017; 52(4):745754.

9. Schmalz G, Davarpanah I, Jager J, Mausberg RF, KrohnGrimberghe B, Schmidt J, Haak R, Sack U, Ziebolz D. MMP-8 and TIMP-1 are associated to periodontal inflammation in patients with rheumatoid arthritis under methotrexate immunosuppression - First results of a cross-sectional study. J Microbiol Immunol Infect2019; 52(3):386-394.

10. Romero-Sanchez C, Rodriguez C, Santos-Moreno $P$, Mesa AM, Lafaurie GI, Giraldo-QS, De-Avila J, Castillo DM, Duran M, Chalem PC, Bello Gualtero JM, ValleOnate $R$. Is the treatment with biological or nonbiological DMARDS a modifier of periodontal condition in patients with rheumatoid arthritis? Curr Rheumatol Rev2017; 13(2):139-151.

11. Chen HH, Chen DY, Lai KL, Chen YM, Chou YJ, Chou P, Lin $\mathrm{CH}$, Huang N. Periodontitis and etanercept discontinuation risk in anti-tumor necrosis factor-naive rheumatoid arthritis patients: A nationwide populationbased cohort study. J Clin Rheumatol2013; 19(8):432438.

Trop J Pharm Res, October 2021; 20(10): 2225 
12. Kobayashi $T$, Yokoyama $T$, Ito $S$, Kobayashi $D$, Yamagata A, Okada M, Oofusa K, Narita I, Murasawa A, Nakazono K, Yoshie H. Periodontal and serum protein profiles in patients with rheumatoid arthritis treated with tumor necrosis factor inhibitor adalimumab. J Periodontol2014; 85(11):1480-1488.

13. Aletaha $D$, Neogi $T$, Silman AJ, Funovits J, Felson DT, Bingham CO 3rd, Birnbaum NS, Burmester GR, Bykerk VP, Cohen MD, Combe B, Costenbader KH, Dougados $M$, Emery $P$, Ferraccioli $G$, Hazes JM, Hobbs $K$, Huizinga TW, Kavanaugh A, Kay J, Kvien TK, Laing T, Mease P, Menard HA, Moreland LW, Naden RL, Pincus $T$, Smolen JS, Stanislawska-Biernat E, Symmons $D$, Tak PP, Upchurch KS, Vencovsky J, Wolfe F, Hawker G. 2010 Rheumatoid arthritis classification criteria: an American College of Rheumatology/European League Against Rheumatism collaborative initiative. Arthritis Rheum2010; 62(9):2569-2581.

14. Barczynska TA, Dura M, Blumfield E, Wegierska M, Zuchowski P, Wilinska-Jankowska A, Jeka S. DAS28 score vs. ultrasound examination for assessment of rheumatoid arthritis disease activity: Comparison and discussion of pros and cons. Reumatologia2015; 53(4):213-218.

15. Zekonis G, Sadzeviciene R, Balnyte I, Noreikiene V, Sidlauskaite GM, Sadzeviciute E, Zekonis J. Clinical and microbiological effects of weekly supragingival irrigation with aerosolized $0.5 \%$ hydrogen peroxide and formation of cavitation bubbles in gingival tissues after this irrigation: A six-month randomized clinical trial. Oxid Med Cell Longev2020. DOI: 10.1155/2020/3852431.

16. Ziebolz D, Pabel SO, Lange K, Krohn-Grimberghe B, Hornecker E, Mausberg RF. Clinical periodontal and microbiologic parameters in patients with rheumatoid arthritis. J Periodontol2011; 82(10):1424-1432.

17. Scher JU, Ubeda C, Equinda M, Khanin R, Buischi $Y$, Viale A, Lipuma L, Attur M, Pillinger MH, Weissmann G, Littman DR, Pamer EG, Bretz WA, Abramson SB. Periodontal disease and the oral microbiota in newonset rheumatoid arthritis. Arthritis Rheum 2012; 64(10): 3083-3094

18. Wolff B, Berger T, Frese C, Max R, Blank N, Lorenz HM, Wolff $D$. Oral status in patients with early rheumatoid arthritis: a prospective, case-control study. Rheumatology 2014; 53(3): 526-531.

19. Muhlberg S, Jager J, Krohn-Grimberghe B, Patschan S, Mausberg RF, Schmalz G, Haak R, Ziebolz D. Oral health-related quality of life depending on oral health in patients with rheumatoid arthritis. Clin Oral Investig 2017; 21(9): 2661-2670.

20. Cheng Z, Meade J, Mankia K, Emery P, Devine DA. Periodontal disease and periodontal bacteria as triggers for rheumatoid arthritis. Best Pract Res Clin Rheumatol 2017; 31(1): 19-30. 